\title{
Haemolacria in a 22-year-old boy
}

\author{
Robert James, ${ }^{1}$ Muralikrishna Bharadhi, ${ }^{1}$ Jessie James ${ }^{2}$
}

${ }^{1}$ Department of Medicine, Andaman and Nicobar Islands Institute of Medical Sciences, Port Blair, Andaman, India ${ }^{2}$ Departemnt of Anatomy, Andaman and Nicobar Islands Institute of Medical Sciences, Port Blair, Andaman, India

\section{Correspondence to}

Dr Robert James,

drjamesrobert@gmail.com

Accepted 7 December 2018

\section{DESCRIPTION}

A 22-year-old boy presented with two episodes of spontaneous blood in tears (figure 1). A detailed history and clinical examination was normal. Examination of the orbits was normal. An in-depth psychosocial analysis was not contributory.

Blood tests including a complete haemogram, liver function tests and bleeding profile were normal. Bleeding time, clotting time, prothrombin time (PT) index and platelet count were also within normal limits. The capillary fragility test was negative.

PT was evaluated for von Willebrand disease. von Willebrand factor (vWF) antigen assay and the functionality of vWF with a glycoprotein Ib binding assay, collagen binding assay, ristocetin cofactor activity and ristocetin-induced platelet agglutination assays were normal. Factor VIII levels are also checked and were found to be normal. Blood tests for dengue, leptospirosis were negative. Conjunctival swab culture was normal. Dacryocyst rhinogram and lacrimal gland biopsy were normal. CT scan of the skull including the orbit and face was normal.

No cause could be attributed to haemolacria in this patient despite an extensive radiological and haematological workup, along with a normal clinical examination. Hence, we presume it to be an idiopathic form of haemolacria. Approximately $30 \%$ of the cases are reported as idiopathic.

Haemolacria is a condition in which the patient has bloody tears, instead of normal watery tears. It is a symptom of a number of diseases. ${ }^{1}$ It may be indicative of a tumour in the lacrimal apparatus. Severe

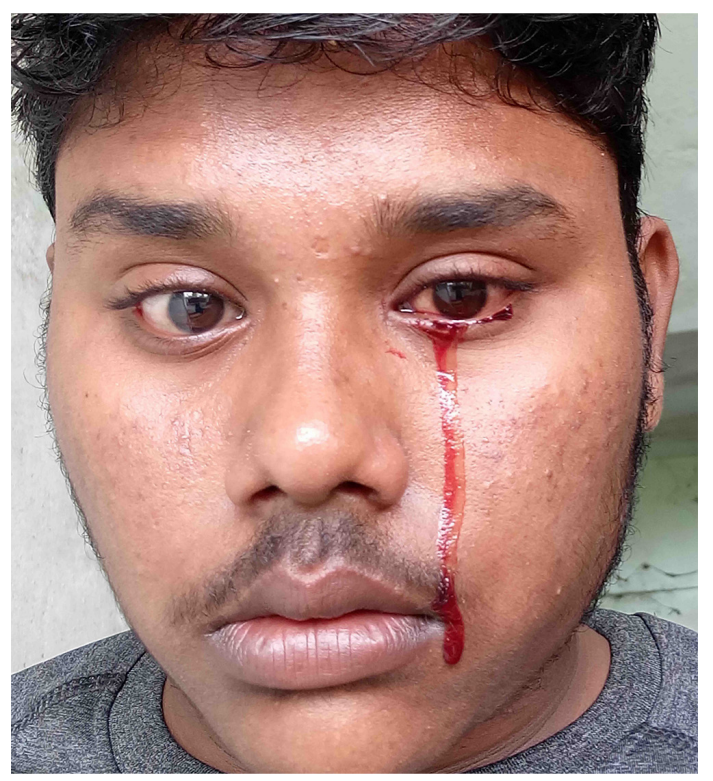

Figure 1 Haemolacria in a 22-year-old boy. bacterial conjunctivitis or local injury to the eye can present with haemolacria. In women ectopic endometrial tissue deposition in the lacrimal duct can give rise to bloody tears during the menstruation. ${ }^{2}$ Pathological enlargement of the venous channels within the orbit and giant papillary conjunctivitis, vascular tumours, Osler-Weber-Rendu disease (hereditary haemorrhagic telangiectasia) haemophilia and other coagulopathies can present with haemolacria. ${ }^{3-5}$

Epistaxis with retrograde blood flow stream into conjunctiva through puncta lacrimalia, Munchausen's syndrome are rare cause of haemolacria. ${ }^{6-8}$

\section{Learning points}

- Haemolacria is a rare medical condition and needs to be investigated more to understand it better.

- A multispecialty approach is needed for evaluation of haemolacria.

Acknowledgements Special thanks to the patient and his family for giving the consent and permission for pts photos to be published.

Contributors RJ: the patient was admitted in my medicine unit III, with bleeding from the eyes. I took detailed patient history and jotted down the clinical findings, and planned the laboratory work for the patient, also helped in online search for related articles and references. MB: the patient was admitted medicine unit III, with bleeding from the eyes. I planned and collected the laboratory reports and investigations and was involved in filing the reports and investigations, also helped in online search for related articles and references. The laboratory reports included bleeding profile, including PT, PTTK, BT, CT, fibrinogen levels, LFT, CBC.

Funding The authors have not declared a specific grant for this research from any funding agency in the public, commercial or not-for-profit sectors.

Competing interests None declared.

Patient consent Obtained.

Provenance and peer review Not commissioned; externally peer reviewed.

\section{REFERENCES}

1 Ahluwalia BK, Khurana AK, Sood S. "Bloody tears". Ind J of Opht 1987;35:41-3.

2 Ottovay E, Norn M. Occult haemolacria in females. Acta Ophthalmol 1991:69:544-6

3 Bonavolanta G, Sammaritino A. Ophthalmologica. , 1981:182, 5 .

4 Richard A, Eifermam HD, Amer J. Ophthalmol. 1982;93:524.

5 Tüfekçi Ö, Gözmen S, Yılmaz Ş, et al. A case with unexplained bleeding from multiple sites: munchausen syndrome by proxy. Pediatr Hematol Oncol 2011;28:439-43.

6 Salvo M, Pinna A, Milia P, et al. Ocular Munchausen syndrome resulting in bilateral blindness. Eur J Ophthalmol 2006;16:654-5.

7 Sridharan S, Shukla D, Mehta R, et al. Munchausen syndrome masquerading as bleeding disorder in a group of pediatric patients. Indian J Psychol Med 2011:33:86-8.

8 Patenaude B, Zitsch R, Hirschi SD. Blood-but not bleeding-at a tracheotomy site: a case of Munchausen's syndrome. Ear Nose Throat J 2006;85:677-9. 
Copyright 2018 BMJ Publishing Group. All rights reserved. For permission to reuse any of this content visit https://www.bmj.com/company/products-services/rights-and-licensing/permissions/

BMJ Case Report Fellows may re-use this article for personal use and teaching without any further permission.

Become a Fellow of BMJ Case Reports today and you can:

- Submit as many cases as you like

- Enjoy fast sympathetic peer review and rapid publication of accepted articles

Access all the published articles

- Re-use any of the published material for personal use and teaching without further permission

For information on Institutional Fellowships contact consortiasales@bmjgroup.com

Visit casereports.bmj.com for more articles like this and to become a Fellow 